\title{
$\Delta$ madridge
}

Interconnecting Scientific World

\section{Madridge Journal of}

Research Article

Open Access

\section{Efficacy of Phytobiotics of Achyranthes splendens (Linn) against Bacterial Pathogens of Male Broiler Chickens in Namakkal, India}

\author{
Yasodha $\mathbf{T}^{*}$, Jeevitha $\mathbf{S}$, Yogesh $\mathbf{S}$ and Ramanan $\mathbf{M}$ \\ Department of Biotechnology, PGP College of Arts and Science, Tamilnadu, India
}

\section{Article Info

*Corresponding author:
Yasodha T
Head
Department of Biotechnology
PGP College of Arts and Science
Tamilnadu
India
E-mail: btmbty@gmail.com

Received: December 14, 2018

Accepted: February 22, 2019

Published: February 28, 2019

Citation: Yasodha T, Jeevitha S, Yogesh S, Ramanan M. Efficacy of Phytobiotics of Achyranthes splendens (Linn) against Bacterial Pathogens of Male Broiler Chickens in Namakkal, India. Madridge J Agric Environ Sci. 2019; 1(1): 26-30.

doi: 10.18689/mjaes-1000105

\begin{abstract}
Copyright: @ 2019 The Author(s). This work is licensed under a Creative Commons Attribution 4.0 International License, which permits unrestricted use, distribution, and reproduction in any medium, provided the original work is properly cited.
\end{abstract}

Published by Madridge Publishers

\begin{abstract}
Phytogenic alternatives drawn a lot of attention because they are natural, non-toxic and residue free. "Phytogenic Alternatives" are the buzz word in livestock field to avoid the use of the antibiotics and chemical growth hormones resulting in health concerns. In the present study Achyranthes splendens (Linn) a medicinal plant was selected for its phytogenic property against bacterial pathogens of broiler chickens.

Effect of selected antibiotics of poultry and leaf extract powder of Achyranthes splendens L., against the poultry pathogens were tested. Collection of pathogens on swab from the intestine on 7, 14 and 21 days was done asceptically and cultured in the lab as a pretreatment study. The results of pretreatment study showed that there is positive trend of pathogenic control by Achyrabiotic from $86.7 \%$ to $100 \%$ when compared to the antibiotics. Efficacy of achyrabiotic in antibacterial assay revealed the phytobiotic nature of the Achyranthes splendens $\mathrm{L}$.

Based on the protein profile of Achyranthes splendens (Linn) by High performance Liquid Chromatography study, the phytogenic characteristics were used for the growth study of broiler chicks. Leaf extract in the form of dry powder was used in the formulations of phytogenic poultry feed. There is no mortality in the organic achyrabiot fed male broiler chicks. Growth performance parameters such as body weight gain (from $24 \%$ to $32 \%$ ), feed intake (2\% to $21 \%$ ) and Feed conversion ratio (from $26 \%$ to $58 \%$ ) revealed the synergistic effect of phytobiotic and anti-pathogenic properties of achyrabiot on poultry growth.
\end{abstract}

Keywords: Antibacterial activity; Phytogenic alternative; Salmonella typhus; Resistance profile; Organic poultry feed; Weight gain.

\section{Introduction}

Phytobiotics represent a wide range of bioactive compounds that can be extracted from various plant sources. Phytobiotics are classified as: (i) Herbs-product from flowering, non-woody and non-persistent plants; (ii) Botanical-entire or processed parts of a plant, e.g., root, leaves, bark; (iii) Essential oils- hydro distilled extracts of volatile plant compounds; (iv) Oleoresins- extracts based on non-aqueous solvents.

Plant-derived products (phytobiotics) are added to the feed in order to improve performance of agricultural livestock are well documented [1-5].

A variety of antibiotics in high dose are used to control many pathogens are increasingly resistant to many commonly used antibiotics including penicillin, macrolides and aminoglycoside [6-8].

Various herbal supplements are used as alternative antibiotic growth promoters in the starter and grower feeds. Better farm management practices are also an essential criteria to sustain the health of livestock [9-15]. 
Hence with this background the present study has been focused to achieve the following objectives.

i) To improve the quality of poultry feed

ii) To control the pathogens and

iii) To curtail the usage of antibiotics as growth promoters.

A trial on the effect of organic poultry feed along with achyrabiot powder as feed additive on growth performance of male broiler chickens was conducted.

\section{Materials and Methods}

\section{Collection and preparation of "achyrabiot"}

Achyranthes splendens (Linn) is a small herb, grows as weed up to one meter in tropical and subtropical regions and available in various places of Tamilnadu. It is medicinally valuable and used for various ailments in humans and an organic feed preparations in aquaculture[5].

The leaves of Achyranthes splendens (Linn) collected from various areas of Namakkal of Tamilnadu were crushed and extract was taken in sterilized petridishes. Air dried crude extract powder of Achyranthes splendens (mentioned in the present study as "achyrabiot") was taken in different concentrations of $0.2,0.4,0.6,0.8$ and $1 \mathrm{mg}$ for the study. The antibacterial activity of the extracts was analyzed and compared with the commercial antibiotics Albac, Tylon and Terramycin which are used as growth hormones.

\section{Experimental diets}

The organic feed formulation for grower is presented in the table 1.

Table 1. Organic feed composition for Growers (11weeks).

\begin{tabular}{|l|c|}
\hline Ingredients & Quantity $(\mathrm{g} / \mathrm{kg})$ \\
\hline Maize & 500 \\
\hline Rice husk (de oiled) & 100 \\
\hline Soya bean meal & 100 \\
\hline Achyrabiot powder & 100 \\
\hline Fish waste powder & 50 \\
\hline Crab shell powder & 50 \\
\hline Dried bone powder & 50 \\
\hline Dried Liver powder & 05 \\
\hline Turmeric powder & 05 \\
\hline Salt & 15 \\
\hline Garlic powder & 10 \\
\hline Ginger powder & 05 \\
\hline Coriander seeds powder & 05 \\
\hline Asafoetida & 05 \\
\hline
\end{tabular}

\section{Pretreatment study}

Collection of microbes for antibacterial assay: The enteric pathogens of intestine of male broiler chicks were collected at 7, 14 and 21 days on cotton swabs. Bacterial strains such as Escherichia coli, Salmonella typhus, Enterococcus faecalis and Shigella dysenteriae were isolated and maintained in Nutrient agar Broth and cultured in Nutrient Agar medium.

Preparation of medium and inoculums: Nutrient agar medium was prepared by dissolving $2.8 \mathrm{~g}$ of nutrient agar in $100 \mathrm{ml}$ of distilled water. The solution was sterilized in an autoclave at $121^{\circ} \mathrm{C}$ for $15 \mathrm{~min}$. It was cooled and poured into sterile Petri dishes to solidify. Each intestinal microbiota was inoculated on agar by streaking with the swab containing inoculum. Rotate the plate by $60^{\circ}$ and repeat the rubbing procedure. This will ensure an equal distribution of the inocula.

Antibiotic discs were kept on the surface of the inoculated plates. The fresh extract of disc was prepared by dipping the $6 \mathrm{~mm}$ Whatman No1 Filter paper in the $0.2,0.4,0.6,0.8$ and 1 $\mathrm{mg}$ aqua extract of achyrabiot discs that were kept in the incubator for complete drying. Maximum of 5 discs were kept in the petriplate.

\section{Management of broilers}

The growth performance trial was carried out at a private layer farm at Mohanur, Namakkal, Tamilnadu, India with a total of 60 grower birds Lohmann breed at 20 birds per group for 11 weeks. The birds were reared in cage with controlled feeding and followed vaccination as per the schedule before the initiation of the experiment. The male chicks were kept for seven days for adaptation and were kept in separate cages and given normal drinking water. The brooding temperature was maintained at $35^{\circ} \mathrm{C}$ initially and it was then gradually lowered by $3^{\circ} \mathrm{C}$ every week until it reached to room temperature (i.e. $26 \pm 1^{\circ} \mathrm{C}$ ).

\section{Body weight gain study and Feed Conversion Ratio (FCR)}

Effect of commercial feed (Control-C) and achyrabiot powder along with organic poultry feed as additive (Treatment-T) in gaining weight of male broiler chickens was experimented and recorded. Mean initial weight of the male chicks from week-1 to week-10 was recorded. Weighing average body weight of male broiler chickens were randomly selected from the control (C) and the treatment (T) in a completely randomly design (CRD).

FCR represents the proportion of food that is converted into meat.

FCR can be calculated over a set period and the formula is

$$
\mathrm{FCR}=\frac{\text { Total quantity of feed consumed/bird in } \mathrm{g}}{\text { Mean body weight gain in } \mathrm{g}}
$$

\section{Statistical analysis}

The data collected on various parameters were subjected to Duncan's test as per the method suggested by Snedecor and Cochran [16].

\section{Results and Discussion}

\section{Antibacterial assay}

Concentrations $0.2,0.4,0.6,0.8$ and $1 \mathrm{mg}$ and the same concentrations of standard antibiotics act on intestinal microbiota viz., Escherichia coli, Salmonella typhus, Enterococcus faecalis and Shigella dysenteriae were recorded with reference to the zone of inhibition in $\mathrm{cm}$ (Table 2 and Figures 1-4). The result was found to be most effective against all tested microorganisms. Maximum inhibition concentration of phytobiotics is 0.8 to $1 \mathrm{mg}$ which is effective against intestinal pathogenic bacteria. 
The experimental results of antibiotic assay against the intestinal bacterial pathogens viz., E.coli, Salmonella typhus, Enterococcus faecalis and Shigella dysenteriae were compared with the efficacy of antibiotic growth hormones (Figures 1-4). Achyrabiot potentiality in controlling these pathogens was on par with the Terramycin.

Hence from the results 0.8 to $1 \mathrm{mg}$ of Achyrabiot per $10 \mathrm{~g}$ of organic feed was recommended for the preparation of organic poultry feed.

The response of $E$. coli to antibiotics Albac, Tylon and Terramycin was maximum upto $2.2 \mathrm{~cm}$ as zone of inhibition. Compared to terramycin the efficacy of antibiotic activity of Achyranthes was $90 \%$ increased. The antibiotic response of other poultry pathogens showed that there is positive trend of pathogenic control by Achyrabiotic, from $86.7 \%$ to $100 \%$ (Table 2).

Similar kind of experimental results showed the efficacy of bioactive compounds of various herbal medicinal plants against poultry pathogens $[4,7,10,17-19]$.

Table 2. Effect of Achyranthes splendens L. against bacterial pathogens of male broiler chickens.

\begin{tabular}{|l|c|c|c|c|}
\hline Antibiotics \& & \multicolumn{4}{|c|}{ Bacterial pathogens } \\
\cline { 2 - 5 } Phytobiotics & E. coli & S. typhus & E. faecalis & S. dysenteriae \\
\hline Albac & $2.2 \pm 0.2$ & $1.9 \pm 0.1$ & $1.8 \pm 0.4$ & $1.8 \pm 0.3$ \\
\hline Tylon & $2.0 \pm 0.3$ & $1.8 \pm 0.3$ & $2.0 \pm 0.1$ & $2.0 \pm 0.2$ \\
\hline Terramycin & $2.2 \pm 0.1$ & $1.9 \pm 0.2$ & $2.1 \pm 0.3$ & $2.1 \pm 0.4$ \\
\hline Achyrabiotic & $2.2 \pm 0.1$ & $1.9 \pm 0.2$ & $2.1 \pm 0.3$ & $2.1 \pm 0.4$ \\
\hline
\end{tabular}

*Results are expressed as the mean value of triplicates. (Diameter of inhibition zone in $\mathrm{cm}$ )

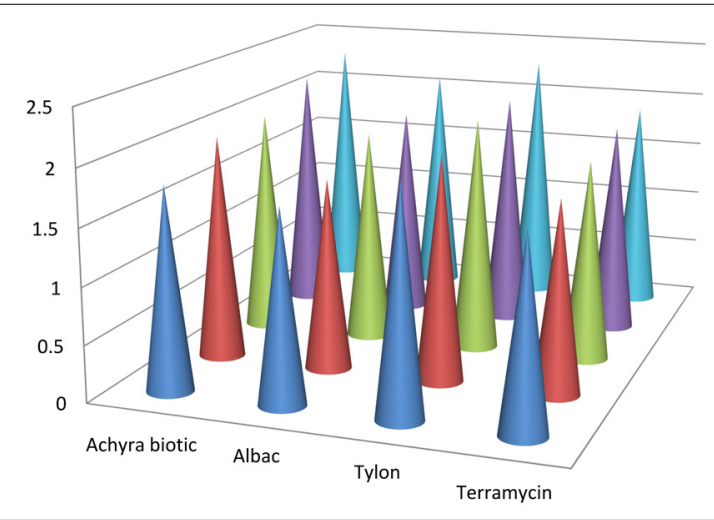

Figure 1. Effect of chemo and phytobiotics on E.coli. (concentration in $\mathrm{mg}$ Vs Zone of inhibition in $\mathrm{cm}$ ).

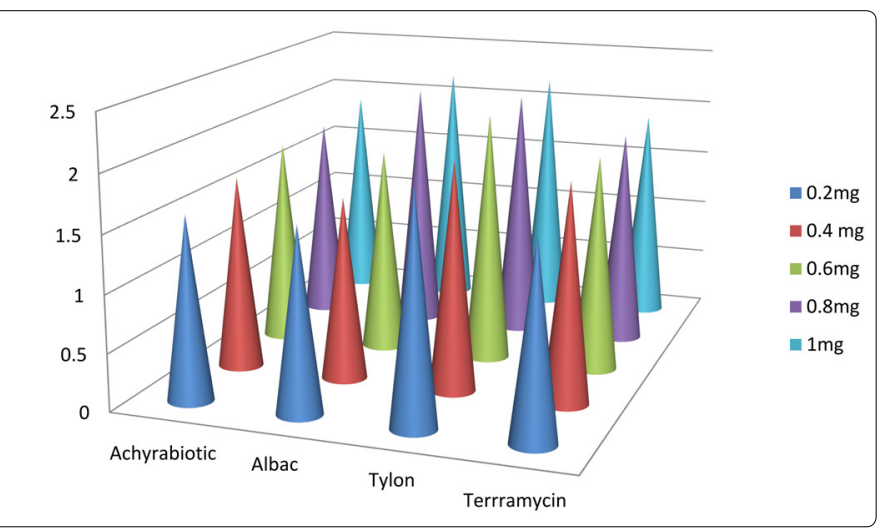

Figure 2. Effect of chemo and phytobiotics on Salmonella typhus. (Concentration in $\mathrm{mg}$ Vs Zone of inhibition in $\mathrm{cm}$ ).

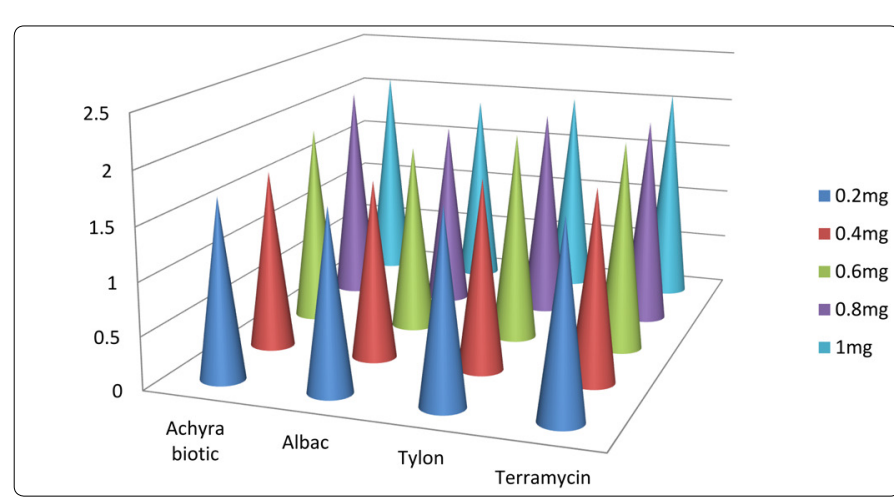

Figure 3. Effect of chemo and phytobiotics on Enterococcus faecalis. (Concentration in $\mathrm{mg}$ Vs Zone of inhibition in $\mathrm{cm}$ ).

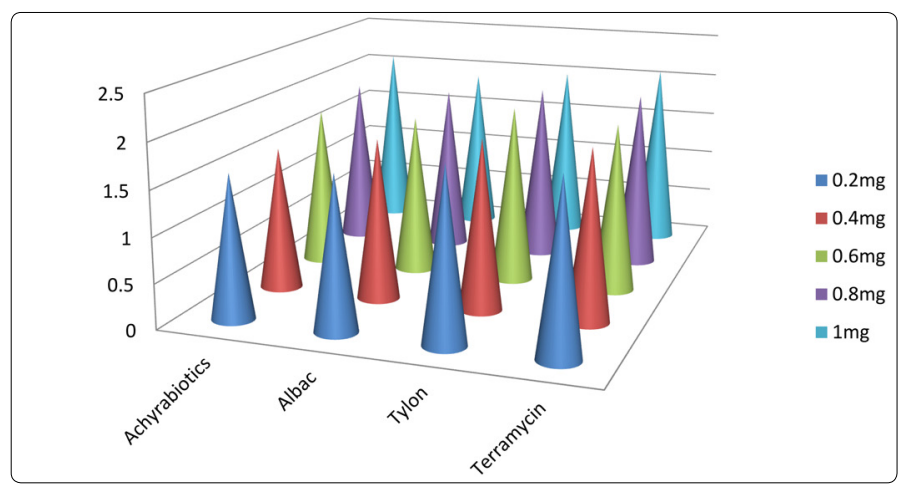

Figure 4. Effect of chemo and phytobiotics on Shigella dysenteriae. (Concentration in $\mathrm{mg}$ Vs Zone of inhibition in $\mathrm{cm}$ )

\section{Feed conversion ratio and body weight gain}

The effects of feeding different concentration of achyrabiot and commercial feed on daily body weight gain are shown in table 3. All groups had initial body weight $550 \pm 1.4 \mathrm{~g}$.

No mortality was detected in the treatment group throughout the study period, where as $2-3 \%$ mortality was observed in the commercial feed with the antibiotic.

These results are in accordance with the experiments of Forder et al. and Brisbin et al. [20,21].

Table 3. Body weight gain of male broiler chicks.

\begin{tabular}{|l|c|c|}
\hline Growth Duration & Commercial feed & $\begin{array}{c}\text { Organic feed with achyrabiot } \\
\text { powder (g) }\end{array}$ \\
\hline Week 1 & $587.95-\mathrm{NS}$ & $589.55-\mathrm{NS}$ \\
\hline Week 2 & $687.05-\mathrm{NS}$ & $697.00-\mathrm{NS}$ \\
\hline Week 3 & $695.53 \pm 0.49$ & $721.00 \pm 0.40$ \\
\hline Week 4 & $723.00 \pm 0.33$ & $785.00 \pm 0.51$ \\
\hline Week 5 & $790.75 \pm 0.33$ & $850.50 \pm 0.51$ \\
\hline Week 6 & $805.25 \pm 0.45$ & $915.25 \pm 0.54$ \\
\hline Week 7 & $875.00 \pm 0.52$ & $995.50 \pm 0.51$ \\
\hline Week 8 & $900.05 \pm 0.55$ & $1012.25 \pm 0.40$ \\
\hline Week 9 & $955.05 \pm 0.59$ & $1120.60 \pm 0.49$ \\
\hline Week 10 & $1008.50 \pm 0.50$ & $1290.75 \pm 0.59$ \\
\hline
\end{tabular}

*Average weight of 20 birds in a cage of triplicates significant at $\mathrm{P}<0.05$; NS-Not Significant

\section{Feed Conversion Ratio (FCR) of male birds}

In every week interval, FCR was calculated where best FCR was found in week-3 to week-10.Feed Conversion Ratio (FCR) is shown in the tables 4 and 5 .

Similar kind of experiments and results recorded by Javed et al. and Senthil Kumar et al. [22,23]. Differences were revealed for FCR in all the treatments from week 2 to week 10 of age. 
Moderate FCR was observed in commercial poultry feed and better FCR was observed in treatment with achyrabiot.

Effective increase in FCR of Group-2 chicks could be due to the quality of feed additive (Figure -5). This view is supported by the experiment done with aquaculture as HPLC study by Thirumal and Laavu [5].

An increasing healthy growth was recorded in the birds fed with achyrabiot as additive feed (Tables 1 and 2). The growth response trend of male broiler chickens showed the positive effect of achyrabiot on gut health and which might be due to the increase in appetite for feed intake from $2.5 \%$ to $21 \%$. This reflects on the body weight gain from $24 \%$ to $32 \%$ in the organic poultry feed (Tables 3 and 4 ).

This is in line of data reported by several authors $[3,15,17,18,20,24]$.

Most essential oils have been classified as generally recognized as safe (GRAS), by the US Food and Drug Administration (FDA). These oils from herbs were subjected to antimicrobial activities with positive influence on poultry growth. Several oils, including carvacrol and thymol obtained from oregano and eugenol from the clove plant, have been shown to inhibit a wide range of pathogenic bacteria [17].

Gut is composed of numerous communities of microorganisms like bacteria, fungi, protozoa and viruses, but bacteria are the predominant microorganisms. The colonization of bacteria in the gut is determined by its substrate preferences and the chemical composition of the contents. To combat the enteric infections and to improve the gut health, antibiotic growth promoters were widely used in poultry feed since last 50 years. But the risk associated with the development of resistant organisms made European Union to ban the use of antibiotics since January $2006[25,26]$.

There is $2-3 \%$ mortality in the Commercial feed (C) group chicks and no mortality in the organic feed treatment (T). Hence the results of our findings obtained on bodyweight gain confirmed the benefits of using botanicals as phytobiotics in influencing the growth performance, in terms of feed intake and feed conversion ratio.

Effect of adding specific botanicals and herb extracts on growth performance/Gut morphology/intestinal microflora were experimented by Chambers and Gong, Wei et al. and Denbow [27-29]. These investigations had shown the beneficial synergistic effect of herbal feed additives in controlling the pathogens and increasing the appetite to increase the body weight gain.

Table 4. Feed intake in male broiler chicks.

\begin{tabular}{|l|c|c|}
\hline Growth Duration & Commercial feed & Organic feed with achyrabiot powder $(\mathrm{g})$ \\
\hline Week 1 & $587.95-\mathrm{NS}$ & $589.55-\mathrm{NS}$ \\
\hline Week 2 & $687.05-\mathrm{NS}$ & $697.00-\mathrm{NS}$ \\
\hline Week 3 & $695.53( \pm 0.49)$ & $721.00( \pm 0.40)$ \\
\hline Week 4 & $723.00( \pm 0.33)$ & $785.00( \pm 0.51)$ \\
\hline Week 5 & $790.75( \pm 0.33)$ & $850.50( \pm 0.51)$ \\
\hline Week 6 & $805.25( \pm 0.45)$ & $915.25( \pm 0.54)$ \\
\hline Week 7 & $875.00( \pm 0.52)$ & $995.50 \pm 0.51$ \\
\hline Week 8 & $900.05( \pm 0.55)$ & $1012.25 \pm 0.40$ \\
\hline Week 9 & $955.05( \pm 0.59)$ & $1120.60 \pm 0.49$ \\
\hline Week 10 & $1008.50( \pm 0.50)$ & $1290.75 \pm 0.59$ \\
\hline
\end{tabular}

${ }^{*}$ Average weight of 20 birds in a cage of triplicates significant at $\mathrm{P}<0.05$; NS-Not Significant

Madridge J Agric Environ Sci.

Volume 1 - Issue $1 \cdot 1000105$

ISSN: 2643-5500
Table 5. Feed Conversion Ratio (FCR) of male broiler chicks.

\begin{tabular}{|l|c|c|}
\hline Growth Duration & Commercial feed & $\begin{array}{c}\text { Organic feed with achyrabiotic } \\
\text { powder }\end{array}$ \\
\hline Week 1 & $1.23 \pm 0.33$ & $1.55 \pm 0.22$ \\
\hline Week 2 & $1.35 \pm 0.22$ & $1.70 \pm 0.23$ \\
\hline Week 3 & $1.39 \pm 0.29$ & $1.89 \pm 0.25$ \\
\hline Week 4 & $1.40 \pm 0.33$ & $1.90 \pm 021$ \\
\hline Week 5 & $1.55 \pm 0.23$ & $2.10 \pm 0.26$ \\
\hline Week 6 & $1.78 \pm 0.25$ & $2.25 \pm 0.52$ \\
\hline Week 7 & $1.74 \pm 0.24$ & $2.50 \pm 0.50$ \\
\hline Week 8 & $1.75 \pm 0.25$ & $2.45 \pm 0.49$ \\
\hline Week 9 & $1.65 \pm 0.29$ & $2.66 \pm 0.49$ \\
\hline Week 10 & $1.70 \pm 0.25$ & $2.75 \pm 0.45$ \\
\hline
\end{tabular}

${ }^{*}$ Average weight of 20 birds in a cage of triplicates -significance level at $\mathrm{P}<0.05$

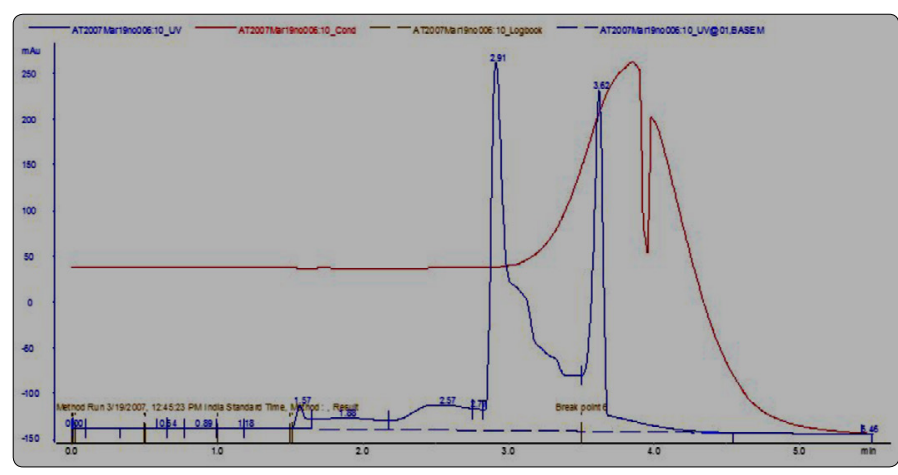

Figure 5. HPLC chromatogram of Protein profile of Achyranthes splendens L. [5].

\section{Conclusion}

Achyranthes splendens L., a medicinal plant was selected for its phytogenic property against bacterial pathogens of male broiler chickens. Pretreatment study revealed the phytobiotic nature of that plant also named "Achyrabiot". Our findings showed $100 \%$ sustainability of poultry health throughout the investigation. Body weight experiments on male broiler chicken using Achyrabiot along with other organic formulations showed its phytobiotic and antipathogenic properties with positive influence on poultry growth. Particularly the aquatic leaf extract powder can be used in the formulations of phytogenic poultry feed. Further investigations will be carried out on the post treatment study to identify gut health. Comparison of health profile of male and female broiler chickens as influenced by the selected phytobiotics will be the future focus of our research.

\section{Acknowledgement}

Authors are thankful to the managing director and the labourers in a private farm of Namakkal District of Tamilnadu, India for having supported this study.

\section{References}

1. Al-Kassie GAM. The effect of thyme and cinnamon on the microbial balance in gastro intestinal tract on broiler chicks. Int J Poult Sci. 2010; 9(5): 495-498.

2. Ancsin Z, Erdélyi M, Mézes M. Effect of rosemary and garlic oil supplementation on glutathione redox system of broiler chickens. Acta Biologica Szegediensis. 2009; 53: 19-21. 
3. Blajman JE, Zbrun MV, Astesana DM, et al. Probiotics in broilers' rearing: A strategy for intensive production models. Revista Argentina de Microbiología. 2015; 47(4): 360-367.

4. Diaz-Sanchez S, D'Souza D, Biswas D, Hanning I. Botanical alternatives to antibiotics for use in organic poultry production. Poult Sci. 2015; 94(6): 1419-1430.

5. Thirumal Y, Laavu S. HPLC Profile of Medicinal Plant Extracts and its Application in Aquaculture. J Aquac Res Development. 2017; 8: 484. doi: 10.4172/2155-9546.1000484.

6. Hoda A, Mohamed F, Abdellatif H, Massoud F. Effect of Bio- tonic on broiler performance. Proceedings of 2 nd Congress, Faculty of Veterinary Medicine, Cairo University. 1992; 134-142.

7. Fricke WF, McDermott PF, Mammel MK, et al. Antimicrobial resistanceconferring plasmids with similarity to virulence plasmids from avian pathogenic Escherichia coli strains in Salmonella enterica serovar Kentucky isolates from poultry. Appl Environ Microbiol. 2009; 75(18): 5963-5971.

8. Carvalho CM, Gannon BW, Halfhide DE, et al. The in vivo efficacy of two administration routes of a phage cocktail to reduce numbers of Campylobacter coli and Campylobacter jejuni in chickens. BMC Microbiology. 2010; 10:232.

9. Youn HJ, Noh JW. Screening of the anticoccidial effects of herb extracts against Eimeria tenella. Vet Parasitol. 2001; 96(4): 257-263.

10. Gaskins HR, Collier CT, Anderson DB. Antibiotics as growth promotants: mode of action. Anim Biotechnol. 2002; 13(1): 29-42.

11. Zhan XA, Hu CH, Xu ZR. Effects of fructo-oligosaccharide on growth performance and intestinal microflora and morphology of broiler chicks. Chinese Journal of Veterinary Science. 2003; 23: 196-198.

12. Chen TC. Effect of adding chicory fructans in feed on broiler growth performance, serum cholesterol and intestinal length. Int J Poult Sci. 2003; 2: $214-219$.

13. $\mathrm{Xu} \mathrm{ZR}, \mathrm{Hu} \mathrm{CH}$, Xia MS, Zhan XA, Wang MQ. Effects of dietary fructooligosaccharide on digestive enzyme activities, intestinal microflora and morphology of male broilers. Poult Sci. 2003; 82:1030-1036.

14. Gabriel I, Lessire M, Mallet S, Guillot JF. Microflora of the digestive tract: critical factors and consequences for poultry. World's Poultry Science Journal. 2006; 62(3): 499-511.

15. Cross DE, McDevitt RM, Hillman K, Acamovic T. The effect of herbs and their associated essential oils on performance, dietary digestibility and gut microflora in chickens from 7 to 28 days of age. Br Poult Sci. 2007; 48: 496-506.
16. Snedecor GW, Cohran WG. Statistical methods. $8^{\text {th }}$ edition. IOWA state University Press/Ames IOWA-50010. 1991.

17. Dorman HJ, Deans SG. Antimicrobial agents from plants: antibacterial activity of plant volatile oils. J Appl Microbiol. 2000; 88(2): 308-316.

18. Carter AJ, Adams MR, Woodward MJ, La Ragione RM. Control strategies for Salmonella colonization of poultry: The probiotic perspective. J Food Sci Technol. 2009; 5(5): 103-115.

19. Deusch S, Tilocca B, Camarinha-Silva A, Seifert J. News in livestock research - Use of omics-technologies to study the microbiota in the gastrointestinal tract of farm animals. Computational and Structural Biotechnology Journal. 2015; 13: 55-63.

20. Forder RE, Howarth GS, Tivey DR, Hughes RJ. Bacterial modulation of small intestinal goblet cells and mucin composition during early posthatch development of poultry. Poult Sci. 2007; 86(11): 2396-2403.

21. Brisbin JT, Gong J, Sharif S. Interactions between commensal bacteria and the gut-associated immune system of the chicken. Anim Health Res Rev. 2008; 9(1): 101-110.

22. Javed M, Durrani F, Hafeez A, Khan RU and Ahmad I. Effect of aqueous extract of plant mixture on carcass quality of broiler chicks. ARPN Journal of Agricultural and Biological Science. 2009; 4: 37-40.

23. Senthilkumar $S$, Madesh N, Purushothaman MR, Vasanthakumar $P$, Thirumalaisamy G, Sasikumar P. Effect of garlic supplementation on performance in broilers-a review. International Journal of Science, Environment and Technology. 2015; 4: 980-983.

24. Danzeisen JL, Kim HB, Isaacson RE, Tu ZJ, Johnson TJ. Modulations of the chicken cecalmicrobiome and metagenome in response to anti-coccidial and growth promoter treatment. PLoS One. 2011; 6(11): e27949.

25. Boamah VE, Agyare $\mathrm{C}$, Odoi $\mathrm{H}$, Dalsgaard A. Practices and factors influencing the use of antibiotics in selected poultry farms in Ghana. Journal of Antimicrobial Agents. 2016; 2(2): 1-8.

26. Carrique-Mas JJ, Trung NV, Hoa NT, et al. Antimicrobial usage in chicken production in the Mekong Delta of Vietnam. Zoonoses Public Health. 2013; 62(1): 70-78.

27. Chambers JR, Gong J. The intestinal microbiota and its modulation for Salmonella control in chickens. Food Res Int. 2011; 44(10): 3149-3159.

28. Wei S, Morrison M, Yu Z. Bacterial census of poultry intestinal microbiome. Poult Sci. 2013; 92(3): 671-683.

29. Denbow DM. Gastrointestinal anatomy and physiology. In: Scanes C (ed). Sturkie's Avian Physiology. 6th edition. Academic Press, New York, NY. 2014: 337-366. 